\title{
Specific ocular changes in TTR Met30-FAP after liver transplantation
}

\author{
Natalia Ferreira ${ }^{1 *}$, David Dias ${ }^{1}$, Carmen Vilas-Boas ${ }^{2}$, Isabel Fonseca ${ }^{2}$, Teresa Coelho ${ }^{3}$ \\ From First European Congress on Hereditary ATTR amyloidosis \\ Paris, France. 2-3 November 2015
}

\section{Purpose}

To report ocular manifestations in Portuguese TTR Met30 FAP patients submitted to liver transplant (LT).

\section{Methods}

Retrospective observational consecutive case series of 78 LT recipients, observed by one ophthalmologist (FN) between January 2007 and July 2015. Demographic data, age at beginning of disease, period of evolution of disease, ophthalmological alterations and ocular surgeries (glaucoma surgery and vitrectomy) were evaluated. Patients were divided in three groups according to date of LT: less than 5 years (group 1); between 5 and 10 years (group 2) and more than 10 years (group 3).

\section{Results}

Thirty-six patients were male. Twelve, 32 and 34 patients belong to group 1, 2 and 3 respectively. The mean age of patients was 41 years (group 1), 44 years (group 2) and 50 years (group 3). Symptoms and signs of dry eye were present in 33\% (group1), 56\% (group 2) and 62\% (group 3 ) of patients. Amyloid deposits on pupillary border were observed in $16 \%, 27 \%$ and $41 \%$ of eyes according to each group. Scalloped pupil was present in 16\%, 25\% and 36\% of cases, respectively. Amyloid vitreous opacities could be seen in $33 \%, 40 \%$ and $59 \%$ of eyes. Vitrectomy and glaucoma surgery was performed in 19 and 24 eyes of group 3 , respectively.

\section{Conclusion}

The prevalence of specific ocular changes increase with time after LT. The need of vitrectomy or glaucoma surgery is common 10 years after LT. Regular ophthalmological evaluation of FAP patients submitted to LT is

'Ophthalmology Department - Centro Hospitalar do Porto - Hospital Santo António (HSA), Porto, Portugal

Full list of author information is available at the end of the article important to accurately treat sight-threatening manifestations.

\begin{abstract}
Authors' details
'Ophthalmology Department - Centro Hospitalar do Porto - Hospital Santo António (HSA), Porto, Portugal. ${ }^{2}$ Centro Hospitalar do Porto, Unidade Corino de Andrade, Porto, Portugal. ${ }^{3}$ Neurology Department - Centro Hospitalar do Porto - HSA, Unidade Corino de Andrade, Porto, Portugal.
\end{abstract}

Published: 2 November 2015

doi:10.1186/1750-1172-10-S1-P64

Cite this article as: Ferreira et al: Specific ocular changes in TTR

Met30-FAP after liver transplantation. Orphanet Journal of Rare Diseases 2015 10(Suppl 1):P64.
Submit your next manuscript to BioMed Central and take full advantage of:

- Convenient online submission

- Thorough peer review

- No space constraints or color figure charges

- Immediate publication on acceptance

- Inclusion in PubMed, CAS, Scopus and Google Scholar

- Research which is freely available for redistribution

Submit your manuscript at www.biomedcentral.com/submit
() Biomed Central 